NBER WORKING PAPER SERIES

\title{
INCENTIVE EFFECTS OF SOCIAL SECURITY UNDER AN UNCERTAIN DISABILITY OPTION
}

\author{
Axel Börsch-Supan \\ Working Paper 7339 \\ http://www.nber.org/papers/w7339 \\ NATIONAL BUREAU OF ECONOMIC RESEARCH \\ 1050 Massachusetts Avenue \\ Cambridge, MA 02138 \\ September 1999
}

Financial support was provided by the DFG through the Sonderforschungbereich 504 and by the National Institute on Aging through the NBER. Comments by Anne Case, David Cutler, and in particular by Daniel McFadden were greatly appreciated. The views expressed herein are those of the authors and not necessarily those of the National Bureau of Economic Research.

(C) 1999 by Axel Börsch-Supan. All rights reserved. Short sections of text, not to exceed two paragraphs, 
may be quoted without explicit permission provided that full credit, including $\odot$ notice, is given to the source. Incentive Effects of Social Security Under

an Uncertain Disability Option

Axel Börsch-Supan

NBER Working Paper No. 7339

September 1999

\begin{abstract}
Incentive effects of pension systems are usually estimated under the assumption that the institutional environment provides a single optimal "pathway" for retirement. However, many countries provide competing pathways which may include several early retirement options in addition to normal retirement. Moreover, early retirement options often comprise special provisions for disabled and unemployed workers that can be strategically manipulated by the employer and the employee while ultimate eligibility for such provisions is uncertain in advance.

This paper shows that ignoring the endogeneity and/or uncertainty in the relevant institutional setting can severely bias the estimates of incentive effects. Ignoring the endogeneity leads to overestimated incentive effects that unduly exaggerate the "pull" view of early retirement. In turn, when the uncertain option set is specified too generously, incentive effects are underestimated. The paper proposes several estimates to bound the true incentive effects of social security on early retirement, and applies them to the German public pension system.
\end{abstract}

\author{
Axel Börsch-Supan \\ Department of Economics \\ University of Mannheim \\ D-68131 Mannheim \\ Germany \\ and NBER \\ axel@econ.uni-mannheim.de
}




\section{INCENTIVE EFFECTS OF SOCIAL SECURITY UNDER AN UNCERTAIN DISABILITY OPTION}

\section{by Axel H. Börsch-Supan}

\section{Introduction}

In most industrialized countries, old age labor force participation has declined dramatically during the last decades. Together with population aging, this puts the social security systems of the industrialized countries under a double threat: Retirees receive pensions for a longer time while there are less workers per retiree to shoulder the financial burden of the pension systems. The decline of old-age labor force participation has therefore turned attention to the incentive effects of social security systems: Is a significant part of the threat homemade because pension systems provide overly strong incentives to retire early? This „pull“ view - labor supply has declined because early retirement provisions pull old workers out of employment - is in contrast to the ,push“ view - a secularly declining demand for labor has created unemployment, and one form is to push older workers into early retirement.

The pull view is prominently put forward in a recent volume edited by Gruber and Wise (1998). The authors from eleven countries argue that the declining old age labor force is strongly correlated with the incentives created by generous early retirement provisions. Formal econometric analyses (e.g.: Stock and Wise, 1990, for the US; Meghir and Whitehouse, 1997, for the UK; Börsch-Supan, 1992, 1999, for Germany) find strongly significant coefficients of variables measuring the incentive effects of pension rules, e.g. the option value to postpone retirement.

Incentive effects of pension rules are usually estimated under the assumption that the institutional environment provides a single optimal "pathway" for retirement. This optimal pathway then defines present values of retirement income at any retirement age, or an option value of postponing retirement at any prospective retirement age. However, most countries provide competing pathways which include several early retirement options in addition to normal retirement, typically at age 65 .

Kohli et al. (1991) have stressed the variety of these pathway options across Europe. Figure 1 shows how important these different exit routes or pathways are in Germany. It is 
particularly impressive that early retirement due to a disability before age 60 (denoted by DI2) was the most common pathway in most of the years 1958-1994, while „normal" retirement (denoted by NR) has a share of less than 20 percent since the mid 1970s. Early retirement due to unemployment (denoted by UN) increased steeply in the early 1990s and accounted for another roughly 20 percent of labor market exits. Complicating this picture even more, the exit routes depicted in Figure 1 are frequently preceded by pre-retirement schemes. These schemes are industry- or company-specific and are popular not only in Germany but also in many other European countries.

Figure 1: Pathways to Retirement

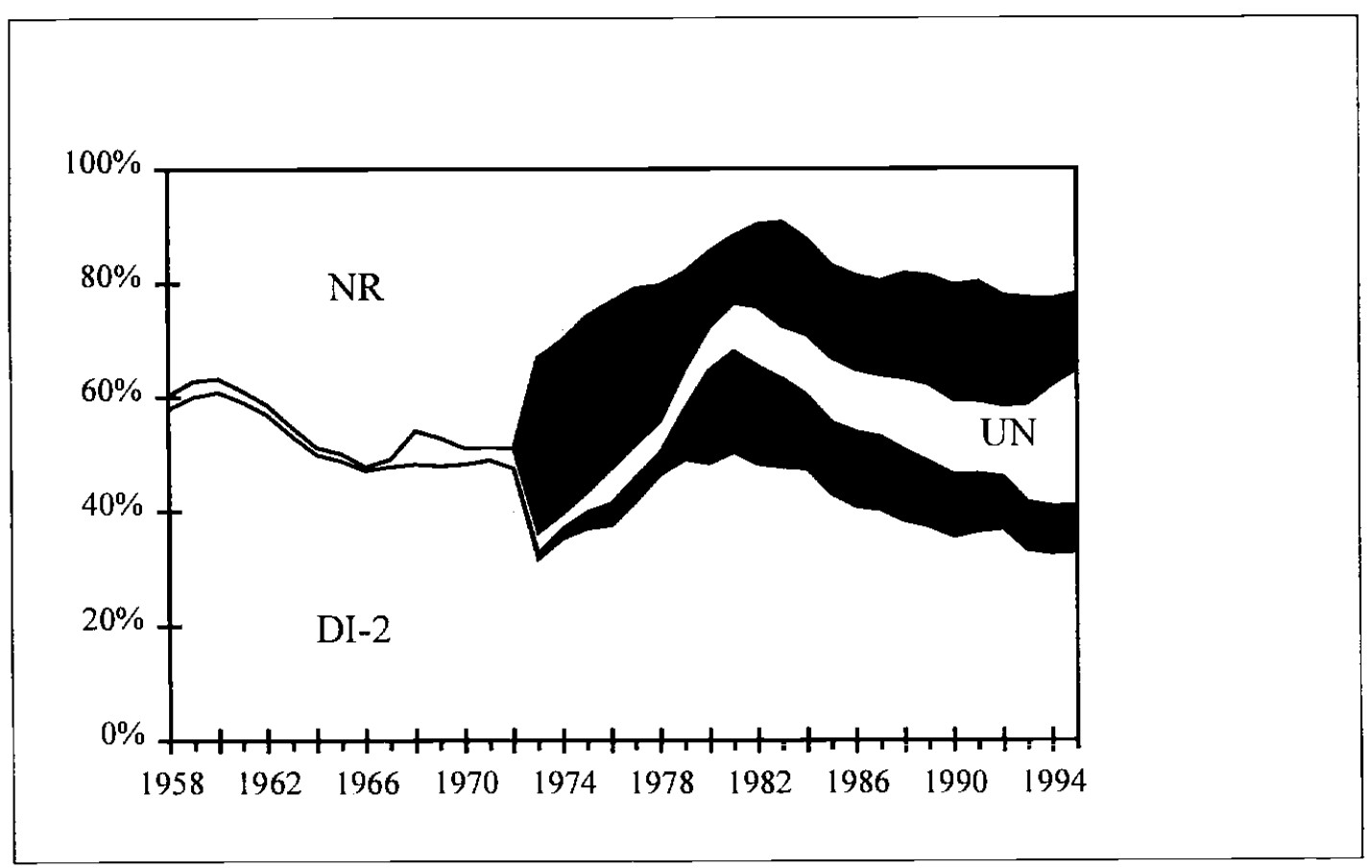

Note: The figure shows the share of pathways by year. The shaded areas are (from top to bottom) NR: Normal retirement; FR: flexible retirement (only after the 1972 reform); UN: early retirement because of unemployment; DI-1: early retirement because of an onset of disability after age 60 (only after the 1972 reform); DI-2: early retirement because of an onset of disability before age 60. Source: Verband deutscher Rentenversicherungsträger, 1997.

When measuring incentive effects, there are two distinct problems associatcd with this multitude of exit routes. First, early retirement options such as the special provisions for disabled and unemployed workers can effectively be strategic variables for the employer and the employee. Employers may have an incentive to let the social security system pay for the costs 
of restructuring their work force, while employees may have an incentive to enjoy leisure early on the expense of the contributors to the social security system. As a result, constructs of incentive effects that rely on indicators for the availability of a certain pathway are endogenous. Prime example for such an indicator is the reported health status, often measured as the extent of disability in percent of full work ability. This is frequently the legal prerequisite for early retirement and can be manipulated at least to some extent as has been controversially discussed by Bound (1989) and Parsons (1991). The complicated interaction between health and the eligibility for disability benefits has been documented by a working group led by John Rust (Benitez aet al., 1998) as a prerequisite for a structural estimation of incentive effects due to disability benefits improving on the large U.S. literature on this topic (see Parsons, 1982; Halpern and Hausman, 1986; Stern, 1989; Rust, 1990; and Rust and Phelan, 1997).

A second technical problem associated with the multitude of exit routes is that the choice of a specific pathway to retirement is made when it is not clear whether certain options are actually relevant for the individual contemplating early retirement. Again, disability is the prime example: even if the reported health status has not been manipulated, econometricians face the problem that the outcome of the screening process for eligibility is far from certain ex ante. If econometricians specify the option set too generously, they exaggerate the incentives at work and thus underestimete the coefficient of the incentive variable. In turn, incentive effects may be overestimated -- and thus the the pull view of early retirement -- if the option set is too restrictive.

This paper shows that ignoring the uncertainty and endogeneity of the relevant institutional setting -- i.e., the available pathways -- can severely bias the estimates of incentive effects. The paper focuses on the disability option that provides particularly strong incentives. It proposes several estimates to bound the „true“ incentive effects of social security on early retirement in the face of uncertainty, and it uses an approximate two-stage procedure to tackle the endogeneity problem.

Section 2 provides the institutional background of the German pension system and the early retirement incentives it creates. Section 3 introduces the data, a sample of German workers aged 55-70 drawn from the German Socio-Economic Panel (GSOEP) and describes patterns of retirement, disability and health in the sample. Section 4 presents estimation re- 
sults for several specifications aimed at correcting for uncertainty and endogeneity of the disability benefit eligibility. Section 5 concludes and draws policy recommendations.

\section{Incentives Created by the German Public Pension System}

The German public pension system is particularly well-suited for a microeconometric study of incentive effects on labor force participation because it is almost universal and we do not need to account for a variety of firm pension plans that create their own incentive effects but are usually not well captured in survey data (Börsch-Supan and Schnabel, 1998). The homogeneity arises for two reasons. First, the German public pension system is mandatory for every worker except for the self-employed and those with very small labor incomes. Because almost all German workers have been dependently employed at least at some point in their working career, almost every worker has a claim on a public pension. Second, the system has a very high replacement rate, generating net retirement incomes that are currently about 70 percent of pre-retirement net earnings for a worker with a 45 -year earnings history and average life-time earnings. This is substantially higher than the corresponding U.S. net replacement rate of about 53 percent. In addition, the system provides relatively generous survivor benefits that constitute a substantial proportion of the total pension liability. As a result, social security income represents about 80 percent of household income of households headed by a person aged 65 and over, the remainder about equally divided among firm pensions, asset income, and private transfers.

Until 1972, retirement was mandatory at age 65 . Early retirement was possible and frequent through the disability pathway, see Figure 1. With the landmark 1972 pension reform, several early retirement options were introduced. Figure 1 shows that early retirement almost instantaneously substituted for a considerable portion of disability benefits - a fairly strong indication that disability status was not only related to health. The pension system established in 1972 now provides old-age pensions for workers aged 60 and older and disability benefits for workers below age 60, that are converted to old-age pensions latest at age 65 .

The main feature of the old-age pensions is "flexible retirement" from age 63 for workers with a long service history. In addition, retirement at age 60 is possible for women, unemployed workers, and workers who cannot be appropriately employed for health or labor market reasons. It is noteworthy that these features were introduced by the 1972 reform as 
social achievements before unemployment started to rise in the mid-seventies. Only later, one realized that they helped to keep the unemployment rate down. 20 years after the introduction of the various early retirement options, the 1992 pension reform is attempting to close some of the early retirement options. However, the effects are irrelevant for our sample as they will only be visible after the year 2004 .

Old-age pension benefits are computed on a life-time contribution basis. They are the product of four elements: (1) the employee's relative wage position, averaged over the entire earnings history, (2) the number of years of service life, (3) several adjustment factors, and (4) the average pension level. The first three factors make up the "personal pension base" which is calculated when entering retirement. Old-age pensions are proportional to length of service life, a specific feature of the German pension system. The fourth factor determines the income distribution between workers and pensioners in general and is adjusted annually to net wages. Thus, productivity gains are transferred each year to all pensioners, not only to new entrants. Due to a generous exemption, social security benefits are tax free unless income from other sources is high.

Early retirement incentives are created by the (lack of) adjustment factors. Before the 1992 pension reform, there was no explicit adjustment of benefits when a worker retired earlier than at age 65, except for a bonus when retirement was postponed from ages 65 or 66 by one year. Nevertheless, because benefits are proportional to the years of service, a worker with fewer years of service would get lower benefits even before the bonus. With a constant income profile and 40 years of service, each year of earlier retirement decreased pension benefits by 2.5 percent. This is substantially less than the actuarial adjustment which increases from about 5.5 percent for postponing retirement one year at age 60 to 8 percent for postponing retirement one year at age 65 . The 1992 pension reform will gradually change this by introducing retirement age-specific adjustment factors to the benefit formula. However, they will remain about 2 percent below those required for actuarial fairness. Figure 2 displays actuarial adjustments as well as those under the current (i.e., relevant for our working sample) and future institutional settings. 


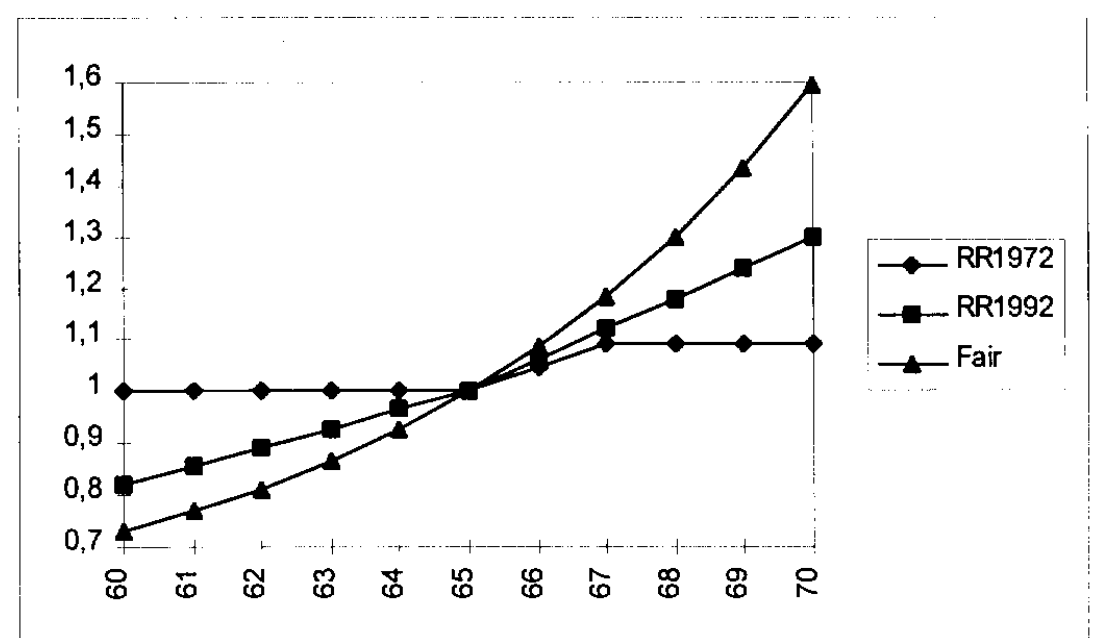

Notes: „RR1972“ denotes the adjustment factors introduced by the 1972 Pension Reform, „RR1992“ symbolizes the adjustments that will be phased in by the 1992 Pension Reform, and „Fair" refers to actuarially fair adjustment factors.

Disability pensions before reaching age 60 are particularly generous. First, the service life used in a similar computation as for old-age pensions is extended by the time between the onset of the disability and age 60, albeit at a reduced earnings base at two thirds of the last earnings. Second, disability benefits are not actuarially adjusted, even after the 1992 reform, but are computed as if the worker had retired at age 60 . Disability pensions after age 60 are computed like old-age pensions, but without actuarial adjustments.

The key statistic to measure the early retirement incentives exerted by the actuarially unfair adjustment factors is the change in social security wealth. If social security wealth declines because the increase in the annual pension is not large enough to offset the shorter time of pension receipt, workers have a financial incentive to retire earlier. We define social security wealth as the expected present discounted value of benefits minus applicable contributions. Seen from the perspective of a worker who is $S$ years old and plans to retire at age $R$, social security wealth $(S S W)$ is

$$
S S W_{S}(R)=\sum_{t=R}^{\infty} Y R E T_{t}(R) \cdot a_{t} \cdot \delta^{t-S}-\sum_{t=S}^{R-1} c \cdot Y L A B_{t} \cdot a_{t} \cdot \delta^{t-S},
$$

with: SSW present discounted value of retirement benefits (=social security wealth), 
$c_{\mathrm{t}} \quad$ contribution rate to pension system at age $t$,

$a_{\mathrm{t}} \quad$ probability to survive at least until age $t$ given survival until age $S$,

$\delta \quad$ discount factor $=1 /(1+r)$.

The accrual rate of social security wealth between age $t-1$ and $t$ is

$$
A C C R S(t)=\left[S S W_{S}(t)-S S W_{S}(t-1)\right] / S S W_{S}(t-1)
$$

A negative accrual can be interpreted as a tax on further labor force participation. It is particularly handy to express this as an implicit tax rate: the ratio of the (negative) social security wealth accrual to the net wages $\left(Y L A B^{\mathrm{NET}}\right)$ that workers would earn if they would postpone retirement by one year

$$
T A X R_{S}(t)=-\left[S S W_{S}(t)-S S W_{S}(t-1)\right] / Y L A B_{\mathrm{t}}^{\mathrm{NET}}
$$

Figure 3 shows that the early retirement incentives created by the old-age pension formula in Germany are strong. We will see below, that the incentives created by disability benefits are even stronger. The accrual function (left panel) has three distinctive kink points. The first kink occurs at age 60 , the earliest retirement age into the public pension system without disability status. Two other kinks are generated by the bonus for postponing retirement at ages 65 and 66, interrupting the steady increase in negative pension wealth accrual.

\section{Figure 3: Loss in Social Security Wealth When Postponing Retirement, (1972 Rules, Old-Age Pensions only)}

Accrual Rate

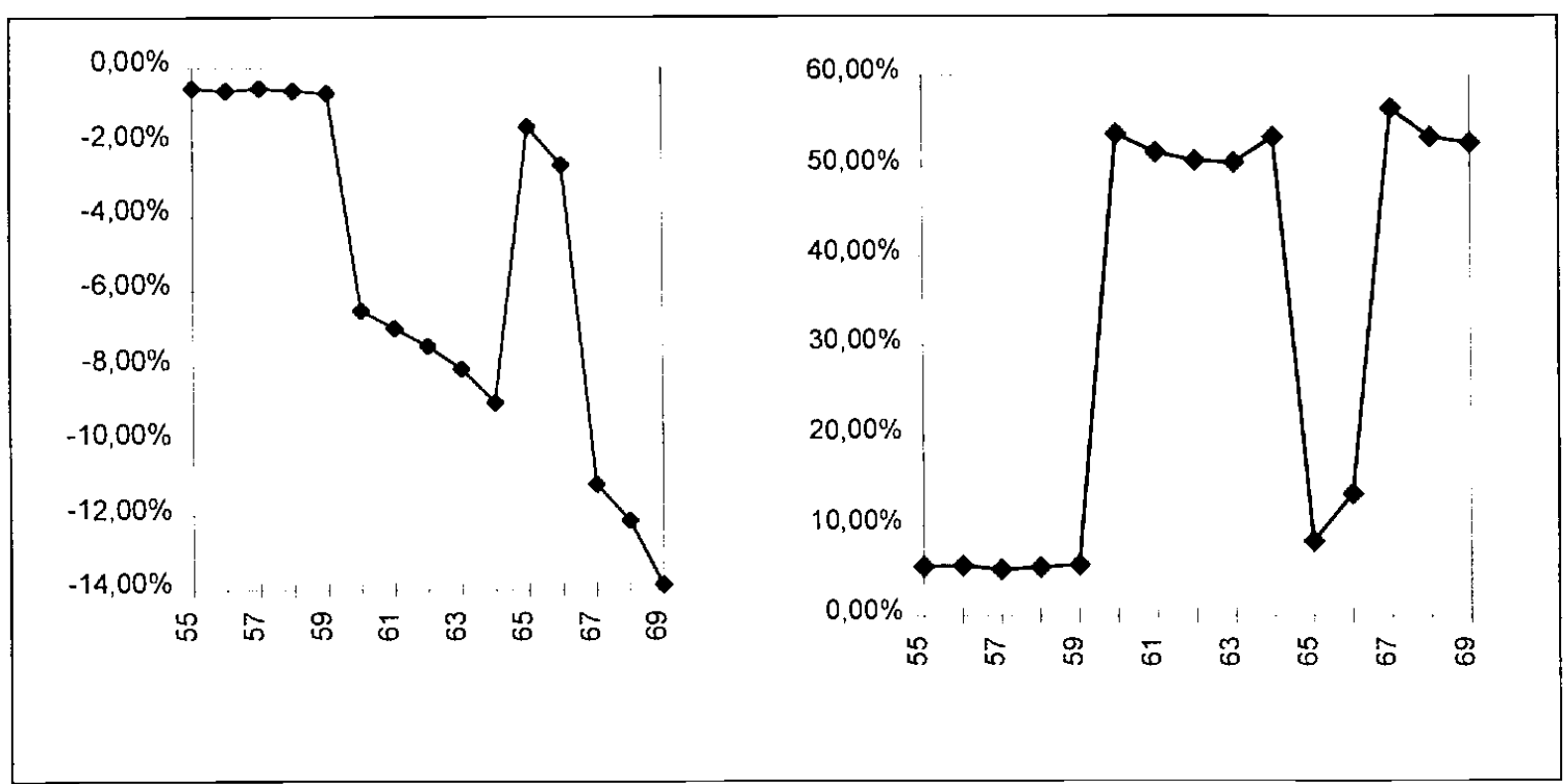

Note: See text for definition of accrual rate $A C C R S(t)$ and implicit tax rate $T A X R_{S}(t)$ for $S=55$ and $t=55 \ldots 69$. 
The lack of actuarial fairness of the old-age pension system creates a negative accrual of pension wealth during the early retirement window at a rate reaching -9 percent when retirement is postponed from age 64 to 65 . In 1995, this was a loss of about DM 22,000 (US \$ 10,500 at purchasing power parity) for the average worker. Expressed as a percentage of annual labor income, the loss corresponds to a "tax" which exceeds 50 percent.

The 1992 Pension Reform will moderate but not abolish this incentive effect. After 2004, when the 1992 reform will have fully be phased in, the negative accrual rate will reach 5 percent, corresponding to an implicit tax rate of almost 30 percent when retirement is postponed by one year at age 64 .

Disability benefits create even stronger labor supply disincentives. The resulting implicit tax rates for postponing retirement are very large, see Figure 4 . They are likely to create strong incentives to manipulate disability eligibility: if there is a chance to claim disability, not taking it corresponds to a 60 percent implicit tax on earnings. 
Figure 4: Implicit Tax on Postponing Retirement, Disability Case

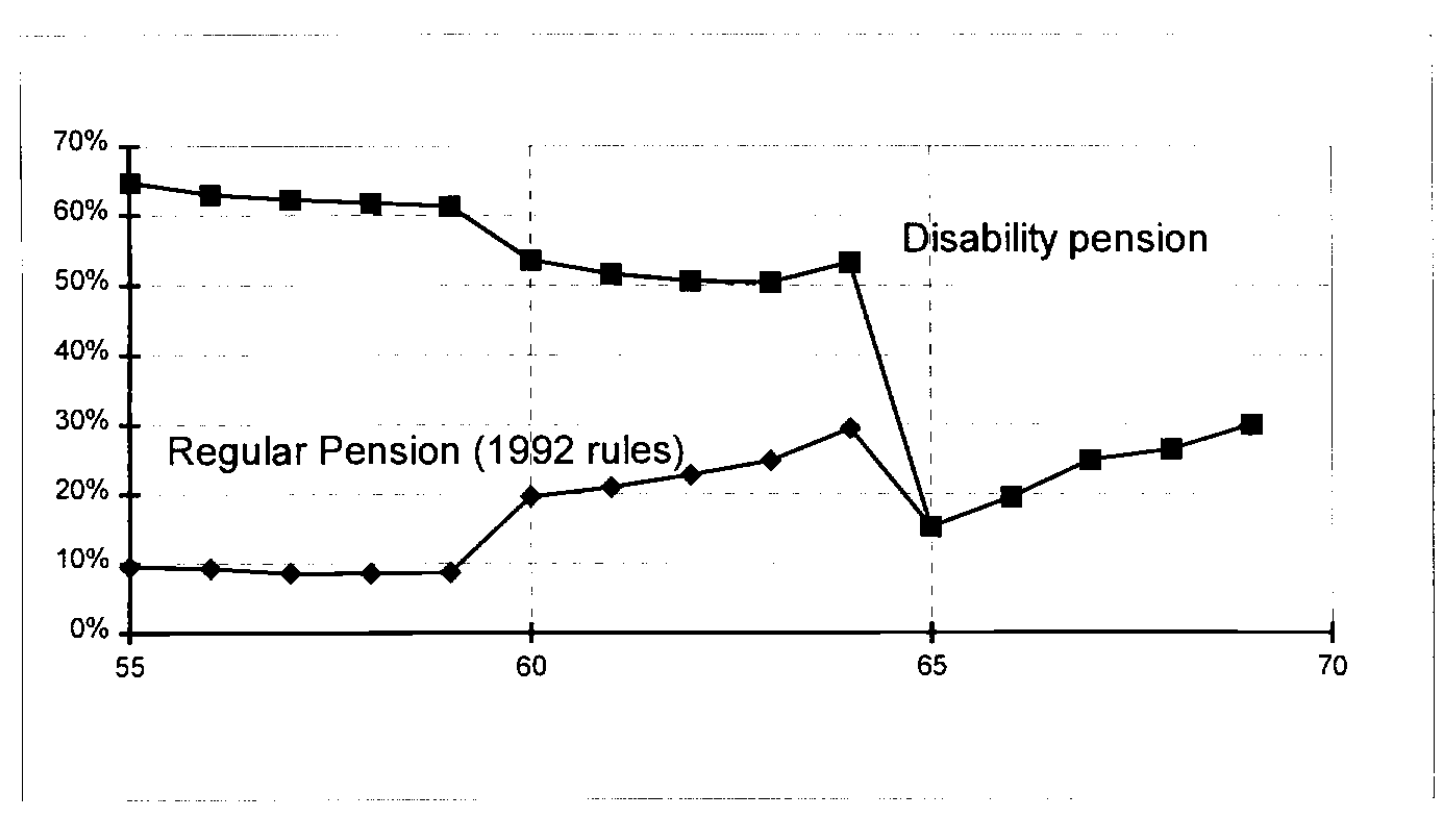

Note: See text for definition of implicit tax rate $T A X R_{S}(t)$.

\section{Data and Descriptive Statistics}

How do these incentives affect actual retirement behavior? We use the 1984-1996 waves of the German Socio-Economic Panel (GSOEP) to tackle this question. The German Socio-Economic Panel (GSOEP) is an annual panel study of some 6000 households and some 15000 individuals. Its design closely corresponds to the U.S. Panel Study of Income Dynamics (PSID). Response rates and panel mortality are also comparable to the PSID. The GSOEP data provide a detailed account of income and employment status. The data is used extensively in Germany, and the increasing interest in the U.S. prompted the construction of an English-language user file available from Richard Burkhauser and his associates at Syracuse University. Burkhauser (1991) reports on the usefulness of the German panel data and provides English-language code books for the internationally accessible GSOEP version. Since 1990, the West German panel was augmented by an East German sample.

For this paper, however, we only use West German workers because prc-retirement is frequent in East Germany and we lack the necessary company-specific information to describe the incentives appropriately. Our working sample consists of all West Germans, who are aged 55 to 70 years and have at least one spell of employment in this "window" in order to rcconstruct an earning history. This working sample includes 1610 individuals. We construct an 
unbalanced panel of these individuals with 8577 observations and an average observation time of 5.3 years. A few sample persons are right-truncated with respect to retirement, i.e., they are employed throughout the entire window period - but most individuals retire before the age of 70. Of the 1987 individuals, 666 have no transitions, 643 have a single transition from employment to retirement, and 301 individuals have more complex histories with at least one reverse transition. 35 percent are female, and the most frequent retirement age is age 60 .

We define a worker to be "retired" when the self-reported employment status is "out of labor force". This includes unemployment workers and workers on pre-retirement who may not receive public pensions but other support ranging from unemoployement benefits to severance pay. Figure 5 depicts the percentage of retired persons in our working sample and shows three distinct jumps: the largest at age 60, and two smaller ones at ages 63 and 65, corresponding to the earliest ages in which the eligibility to various pension types begins, see Section 2. There are very few individuals working after age 65. These patterns in our working sample strongly correspond to administrative records, e.g., VdR (1997). Even before official old age retirement begins, about 15 percent of the workers have retired. This percentage in our working sample is somewhat lower than in the administrative records, depicted in Figure 1 , indicating that the working sample underrepresents "problem cases" who retire very early. This reflects the middle class bias typical for the GSOEP.

Figure 5: Self-Reported Retirement by Age

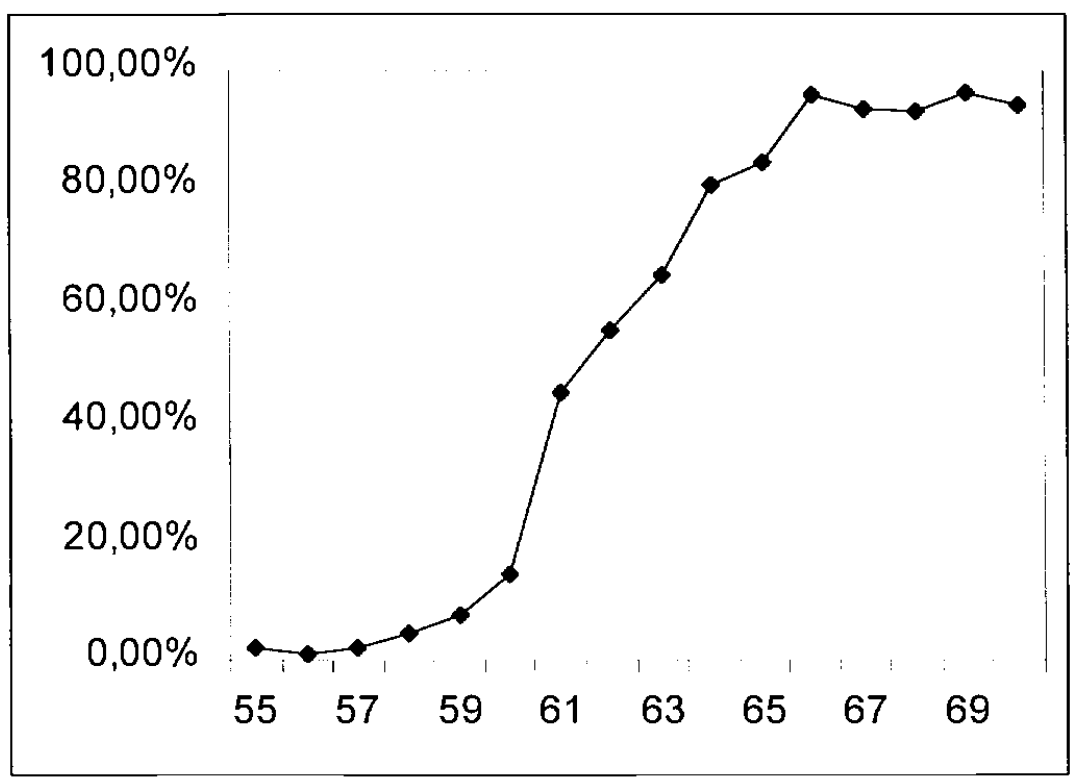

Source: GSOEP 1984-1996, and author's calculations. 
The jump at age 60 is due to three institutional features. Women with a work history of at least 15 years may retire at age 60; any unemployed worker may retire at age 60 if certain mild requirements are satisfied; and, most importantly, workers who are able to claim "oldage disability" which has weaker health and job status requirements than disability before age 60.

"Disability" is officially measured as percent of earnings capability. If this falls below 50 percent, workers can claim a disability pension after age 60 that corresponds to a normal pension, without actuarial adjustments. Indeed, the average degree of disability in the sample increases steadily until age 62 where it reaches 20 percent. After age 63, it increases much slower, see Figure 6.

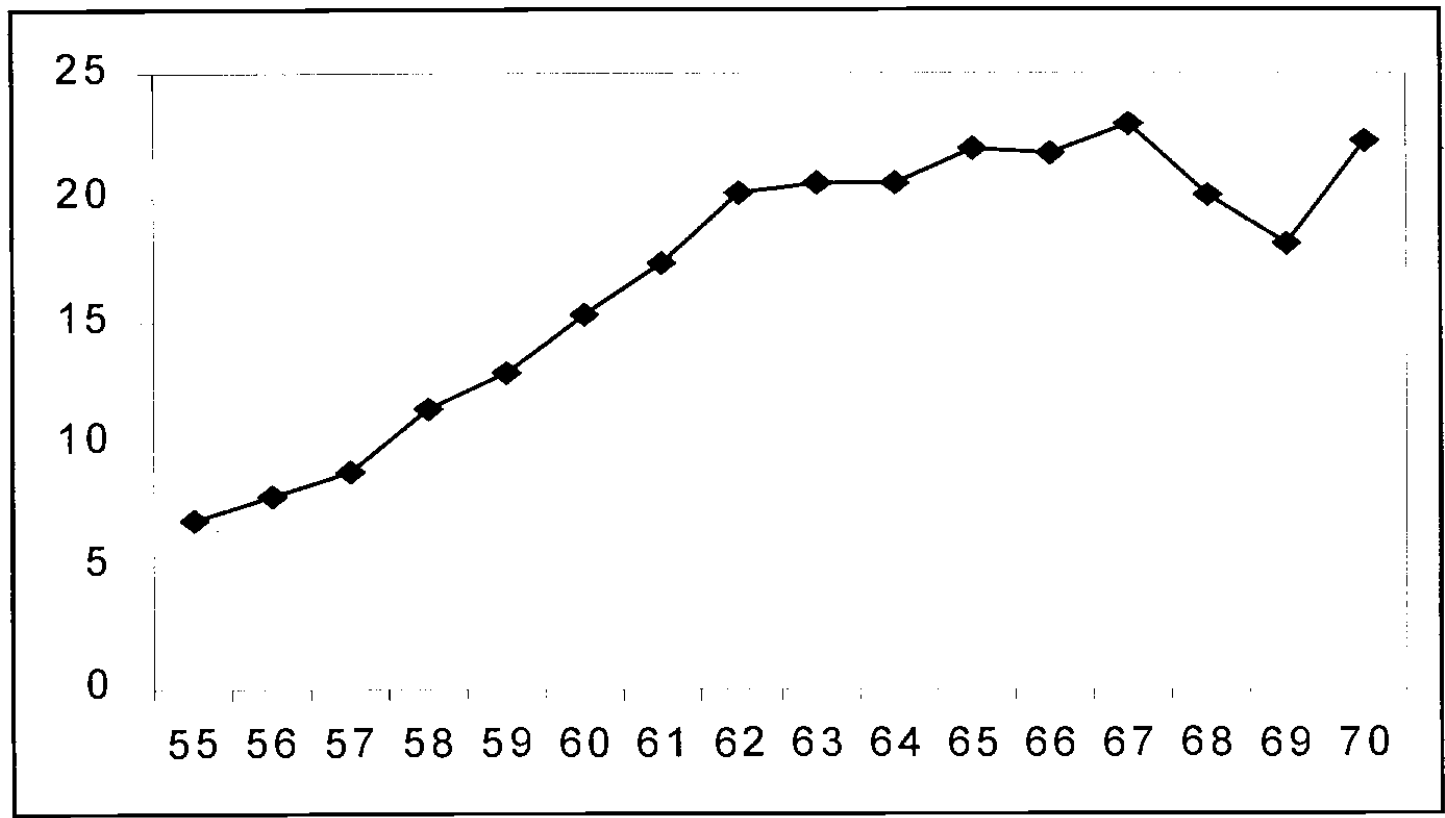

Figure 6: Average Degree of Disability by Age (Percentage)

Source: GSOEP 1984-1996, and author's calculations.

Since it seems implausible that this sudden change is caused by a change in health status, this pattern suggests an institutional reason. It is easy to find. From age 63 on, all male workers can receive a normal pension, provided they have 35 years of work which most male workers have. In fact, a striking finding is the weak correlation between the degree of 
disability and self-reported health. Figure 7 shows that self reported health changes very little, and while a regression of the degree of disability on self-reported health features a significant positive correlation between bad health and disability, its $\mathrm{R}^{2}$ is only about 3 percent.

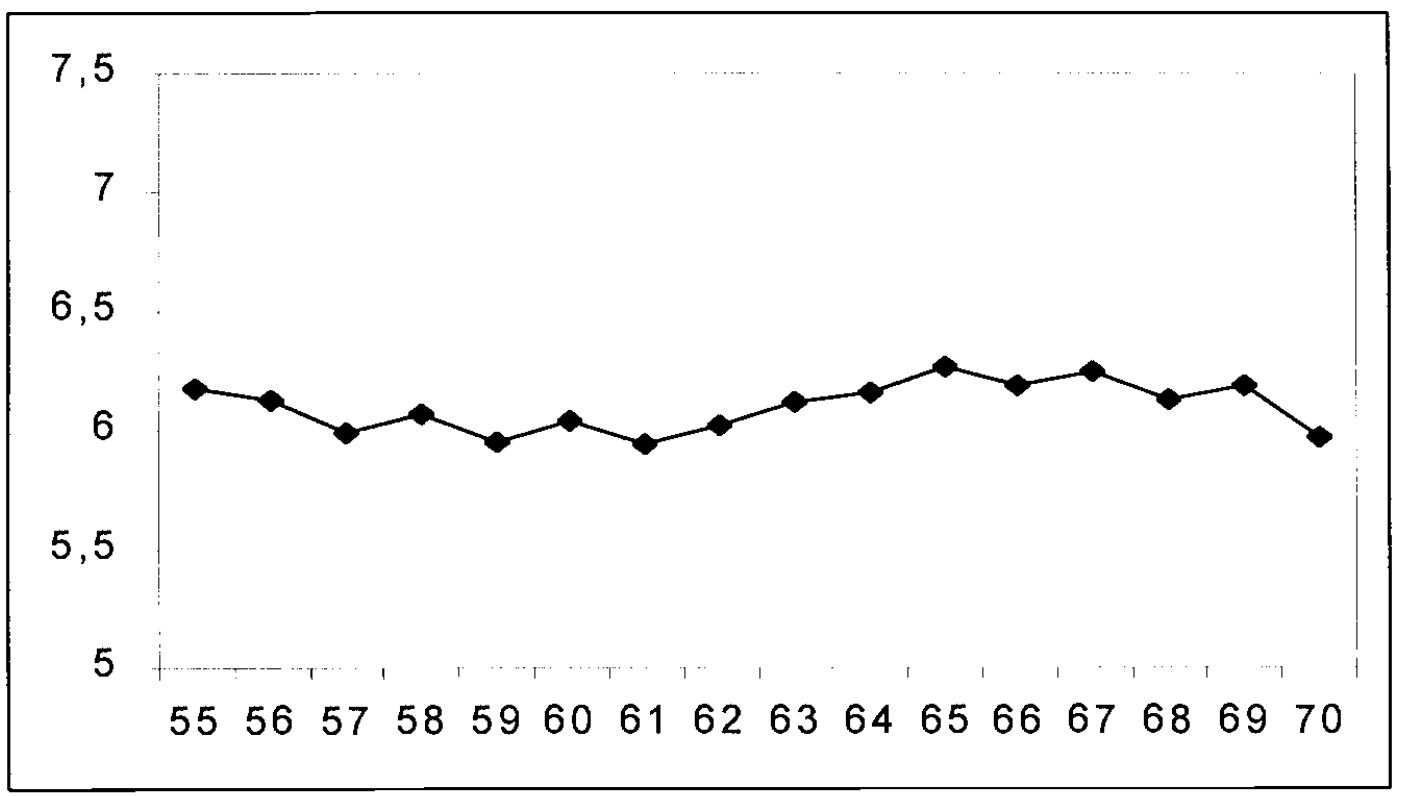

Figure 7: Average Self-Reported Health on a Scale 0-10

Source: GSOEP 1984-1996, and author's calculations.

Partly, this weak correlation is due to the fact that disability status is granted not only for health but also for employment-related reasons. Even healthy workers are classified as "disabled" if there are no jobs available for their specific skills. Leniency in those regulations has changed frequently and unpredictably. They were subject not only to government policy (e.g., in order to manipulate the unemployment rate) but also to law cases (which for example at some point ruled that earnings tests for disabled workers were illegal).

\section{Alternative Estimates of Incentive Effects to Retire Early}

The evidence in the previous section suggests that disability is an important mechanism for early retirement. However, even in the lenient German system, disability is not granted automatically. Only 16 percent in our working sample report a disability status of 50 or more percent. And the discussion at the end of the preceding section has shown that in planning ahead for the choice of retirement age, it is far from clear whether this exit pathway can be taken. 
Incentives for early retirement thus have a strong element of uncertainty which has to built into measures of incentive effects.

We capture the economic incentives provided by the pension system by the option value to postpone retirement (Stock and Wise, 1990). This value captures for each retirement age the trade-off between retiring now (resulting in a stream of retirement benefits that depends on this retirement age) and keeping all options open for some later retirement date (with associated streams of first labor, then retirement incomes for all possible later retirement ages). Consequently, the option value for a specific age is defined as the difference between the maximum attainable consumption utility if the worker postpones retirement to some later year minus the utility of consumption that the worker can afford if the worker would retire now. The definition corresponds closely to the construction of social security wealth in the preceding section.

Let $V_{t}(R)$ denote the expected discounted future utility at age $t$ if the worker retires at age $\mathrm{R}$. Let $\mathrm{R}^{*}(\mathrm{t})$ denote the optimal retirement age if the worker postpones retirement past age $t$, i.e., $\max \left(V_{t}(r)\right)$ for $r>t$. With this notation, the option value is

$$
G(t)=V_{i}\left(R^{*}(t)\right)-V_{i}(t)
$$

Since a worker is likely to retire as soon as the utility of the option to postpone retirement becomes smaller than the utility of retiring now, retirement probabilities should depend negatively on the option value.

We specify the expected utility as follows:

$$
\begin{array}{lll}
,(R)=\sum_{s=1}^{R-1} \mathrm{u}\left(Y L A B_{s}\right) \cdot a_{s} \cdot \delta^{s-t}+\alpha \sum_{s=R}^{\infty} \mathrm{u}\left(Y R E T_{s}(R)\right) \cdot a_{s} \cdot \delta^{s-t} \\
\text { with } & Y L A B_{\mathrm{s}} & \text { Labor income at age } \mathrm{s}, \mathrm{s}=\mathrm{t} . . \mathrm{R}-1, \\
& Y R E T_{S}(R) & \text { Expected retirement income at age } \mathrm{s}, \mathrm{s}>\mathrm{R}, \\
\mathrm{R} & \text { Retirement age, } \\
\alpha & \text { Marginal utility of leisure, to be estimated, } \\
\mathrm{a} & \text { Probability to survive at least until age } \mathrm{s}, \\
\delta & \text { Discount factor, set at } 3 \text { percent. }
\end{array}
$$

To capture the utility from leisure, utility during retirement is weighted by $\alpha>1$, where $1 / \alpha$ is the marginal disutility of work. We use an estimate of $\alpha=3.13$ that was obtained by grid search, see Börsch-Supan (1999). A dollar that has to be earned by work is therefore valued at only about a third of a dollar that is given as a public transfer through the retirement 
system. This value is somewhat higher than estimates for the U.S. (Stock and Wise, 1990) but not implausible for Germany with an arguably higher preference for leisure. We apply a very simple utility function by identifying consumption with income. Preliminary estimates with an isoelastic utility function, $u(Y)=Y^{\gamma}$, yield a $\gamma$ coefficient that is not significantly different from one. Finally, the discount factor $\delta$ is assumed to be 3 percent. Other discount factors in the range between 1 and 6 percent yield qualitatively similar results.

Uncertainty enters the option value through future income. For labor income, we assume this away: it is assumed to be constant after age 55. This is typical for German workers who have seniority rules that flatten out about this age. However, retirement income depends on retirement age and the rules applicable to the individual at that age. As stressed before, it is uncertain which rules will actually apply.

The common procedure in the literature is to use the retirement income according to the rules that have ex post been applied to the sample individual. This procedure is correct for fixed personal characteristics. For example, as pointed out in Section 2, German public pension rules have a more generous retirement age for women than for men. Hence, male persons are assigned pension rules for males, females likewise.

Similarly, the literature has typically assigned disabled individuals a pension according to the rules for disabled workers. However, as opposed to fixed characteristics such as gender, this procedure ignores both uncertainty and potential endogeneity. First, the option value approach is an ex ante, not an ex post view of the utility of a certain retirement age. The ex ante uncertainty cannot be resolved by the econometrician by using its ex post value. Rather, one needs to use the expected value applicable at the time of decision making. Specifically, the ability to claim disability status is not certain at age 55 , the beginning of our decision window. The retirement income YRET in the above equation should therefore be a probability-weighted sum of the relevant pathways, in our simple case "disability" and "normal retirement".

Moreover, as stressed before, eligibility can be manipulated to some extent, and there are strong incentives to do so. Thus, the probability of taking this pathway is potentially endogenous. We therefore have to use an instrumental variable approach to compute fitted probabilities of the pathways "disability" and "normal retirement". This leads us to four variants of the option value to postpone retirement: 
- The tough variant: all individuals are assigned retirement incomes according to normal retirement rules

- The generous variant: all individuals are assigned retirement incomes as if they could claim disability benefits

- The endogenous variant: disabled persons are assigned disability pensions, non-disabled persons normal pensions

- The probabilistic variant: individuals are assigned an expected value, where disability pensions are weighted by a probability $p$, and normal pensions with $(1-p)$. Taking the endogeneity of $p$ into account, we use three instrumental variable approaches:

(a) we use the population frequency of being disabled (15.97 percent),

(b) we regress the probability of having a degree of disability of 50 percent or higher on a cubic polynomial in age and use this fitted values as probability $p$,

(c) we regress the probability of having a degree of disability of 50 percent or higher on a cubic polynomial in age, a set of branch and education dummies, plus gender and marital status, and use this fitted values as probability $p$.

We then insert the resulting option value into a discrete choice model with "retired" as dependent variable, and add the usual suspects as other explanatory variables: an array of socioeconomic variables such as gender, marital status, wealth (indicator variables of several financial and real wealth categories) and a self-assessed health measure. Obviously, we cannot use the legal disability status as a measure of health since this is potentially endogenous.

Inserting the option value in a regression-type model is much less computationally involved and more practical than the estimation procedure employed by Stock and Wise (1990) which in turn much closer approximates the underlying dynamic programming structure (Rust and Phelan, 1997), see Lumbsdaine, Stock and Wise (1992). The regression approach generates robust estimates of the average effects of the option value on retirement, although it is inferior in predicting individual choices when incentives vary widely across individuals.

We begin by using a simple logit model. Table 1 presents a summary, Table 2 the full range of results. 
Table 1: Option value coefficients for 6 variants of expected retirement income

\begin{tabular}{lccc}
\hline & \multicolumn{2}{c}{$\begin{array}{c}\text { Estimated coefficient of } \\
\text { option value (std.error) }\end{array}$} & t-Statistic \\
\hline MODEL 1: „Generous Variant“ & 0,0053 & $(0,00115)$ & 4,63 \\
MODEL 2: „Tough Variant“ & $-0,0046$ & $(0,00098)$ & $-4,72$ \\
MODEL 3: Endogenous Variant & $-0,0096$ & $(0,00080)$ & $-12,02$ \\
MODEL 4a: p=sample freq. & $-0,0034$ & $(0,00122)$ & $-2,79$ \\
MODEL 4b: p=age polynomial & $-0,0038$ & $(0,00116)$ & $-3,28$ \\
MODEL 4c: $\quad$ p=full regression & $-0,0032$ & $(0,00114)$ & $-2,84$ \\
\hline
\end{tabular}

In the "generous" specification of expected retirement income - everybody is eligible for disability benefits" - the sign of the option value coefficient is counterintuitive. All other specifications have the expected negative sign: an increase in the option value to postpone retirement decreases the probability of being retired. The probabilistic variants are very close to each other and are bracketed by the "generous" and the "tough variant". The first-stage $\mathrm{R}^{2} \mathrm{~s}$ in the last two specifications are 8 and 15 percent, respectively. The "endogenous specification", however, is far outside this bracket, considerably larger and with an (apparent) very high precision as indicated by the t-statistic. The endogeneity bias produces a threefold higher estimate of the option value coefficient than the probability-weighted specifications.

Table 2 presents the full results. A positive coefficient indicates that the corresponding explanatory variables increases the probability of retirement. In addition to the option value, health, and an array of socio-economic variables, we include a full set of age dummies to non-parametrically capture all other unmeasured effects on the retirement decision that are systematically related to age, such as social customs. The reference category is age 65 . 


\begin{tabular}{|c|c|c|c|c|c|c|}
\hline \multirow[b]{2}{*}{ Variable } & \multicolumn{2}{|c|}{$\begin{array}{c}\text { MODEL 1: } \\
\text { „Generous Variant“ }\end{array}$} & \multicolumn{2}{|c|}{$\begin{array}{c}\text { MODEL 2: } \\
\text { „Tough Variant“" }\end{array}$} & \multicolumn{2}{|c|}{$\begin{array}{c}\text { MODEL 3: } \\
\text { Endogenous Variant }\end{array}$} \\
\hline & Parameter & t-Stat & Parameter & t-Stat & Parameter & t-Stat \\
\hline Option value & 0,0053 & 4,63 & $-0,0046$ & $-4,72$ & $-0,0096$ & $-12,02$ \\
\hline Health & $-0,1781$ & $-9,83$ & $-0,1803$ & $-9,96$ & $-0,1512$ & $-8,23$ \\
\hline Female & 0,0995 & 1,10 & 0,0434 & $0, \overline{46}$ & 0,0277 & 0,33 \\
\hline Married & $-0,0404$ & $-0,41$ & $-0,0394$ & $-0,40$ & $-0,0461$ & $-0,47$ \\
\hline Education & $-0,6230$ & $-4,73$ & $-0,6166$ & $-4,60$ & $-0,5811$ & $-4,23$ \\
\hline Civil servant & 0,4733 & 3,29 & 0,4988 & 3,38 & 0,4860 & 3,22 \\
\hline Firm pension & $-2,7015$ & $-10,15$ & $-2,7712$ & $-10,31$ & $-2,7925$ & $-10,33$ \\
\hline Life insurance & $-0,0997$ & $-1,27$ & $-0,1104$ & $-1,40$ & $-0,1496$ & $-1,88$ \\
\hline Stocks/bonds & 0,0280 & 0,30 & 0,0089 & 0,09 & 0,0135 & 0,14 \\
\hline Real estate & $-0,8257$ & $-7,55$ & $-0,8019$ & $-7,33$ & $-0,8212$ & $-7,43$ \\
\hline Owner occup. & 0,3148 & 3,76 & 0,3214 & 3,84 & 0,3423 & 4,04 \\
\hline Age $\leq 59$ & $-5,2324$ & $-29,33$ & $-4,6547$ & $-21,32$ & $-4,3121$ & $-22,86$ \\
\hline Age $=60$ & $-3,4990$ & $-17,93$ & $-3,2143$ & $-15,51$ & $-3,0945$ & $-15,60$ \\
\hline Age $=61$ & $-1,8945$ & $-10,67$ & $-1,6760$ & $-8,99$ & $-1,5080$ & $-8,33$ \\
\hline Age $=62$ & $-1,4035$ & $-7,79$ & $-1,2739$ & $-6,93$ & $-1,1792$ & $-6,51$ \\
\hline Age $=63$ & $-1,0178$ & $-5,48$ & $-1,1048$ & $-5,98$ & $-1,1363$ & $-6,15$ \\
\hline Age $=64$ & $-0,2414$ & $-1,20$ & $-0,3323$ & $-1,66$ & $-0,3682$ & $-1,84$ \\
\hline Age $=66$ & 1,4228 & 4,36 & 1,3819 & 4,24 & 1,3616 & 4,18 \\
\hline Age $=67$ & 0,9167 & 3,15 & 0,7985 & 2,75 & 0,7402 & 2,55 \\
\hline Age $\geq 68$ & 1,0680 & 4,27 & 1,0241 & 4,10 & 1,0025 & 4,01 \\
\hline Constant & 3,1187 & 14,27 & 2,9654 & 13,67 & 2,7042 & 12,41 \\
\hline Log likelihood & \multicolumn{2}{|c|}{$-2338,1$} & \multicolumn{2}{|c|}{$-2336,1$} & \multicolumn{2}{|c|}{$-2271,1$} \\
\hline Observations & \multicolumn{2}{|c|}{8577} & \multicolumn{2}{|c|}{8577} & \multicolumn{2}{|c|}{8577} \\
\hline
\end{tabular}

Notes: Dependent variable is dummy variable „retired“. Log likelihood value at zero is 5954.1. 
Table 2(b): Logit model of the retirement decision: Probabilistic Variants

\begin{tabular}{|c|c|c|c|c|c|c|}
\hline \multirow[b]{2}{*}{ Variable } & \multicolumn{2}{|c|}{$\begin{array}{c}\text { MODEL 4a: } \\
p=\text { sample freq. }\end{array}$} & \multicolumn{2}{|c|}{$\begin{array}{c}\text { MODEL 4b: } \\
\text { p=age polynomial }\end{array}$} & \multicolumn{2}{|c|}{$\begin{array}{c}\text { MODEL 4c: } \\
p=\text { full regression }\end{array}$} \\
\hline & Parameter & $t-S t a t$ & Parameter & $t-S t a t$ & Parameter & t-Stat \\
\hline Option value & $-0,0034$ & $-2,79$ & $-0,0038$ & $-3,28$ & $-0,0032$ & $-2,84$ \\
\hline Health & $-0,1813$ & $-10,02$ & $-0,1810$ & $-10,01$ & $-0,1804$ & $-9,98$ \\
\hline Female & 0,1553 & 1,72 & 0,1416 & 1,58 & 0,1711 & 1,94 \\
\hline Married & $-0,0358$ & $-0,36$ & $-0,0376$ & $-0,38$ & $-0,0437$ & $-0,44$ \\
\hline Education & $-0,6303$ & $-4,74$ & $-0,6295$ & $-4,72$ & $-0,6199$ & $-4,65$ \\
\hline Civil servant & 0,4691 & 3,23 & 0,4719 & 3,24 & 0,4493 & 3,11 \\
\hline Firm pension & $-2,7551$ & $-10,29$ & $-2,7604$ & $-10,31$ & $-2,7516$ & $-10,29$ \\
\hline Life insurance & $-0,1166$ & $-1,48$ & $-0,1154$ & $-1,47$ & $-0,1178$ & $-1,50$ \\
\hline Stocks/bonds & $-0,0018$ & $-0,02$ & $-0,0007$ & $-0,01$ & $-0,0014$ & $-0,02$ \\
\hline Real estate & $-0,7984$ & $-7,31$ & $-0,7993$ & $-7,32$ & $-0,7961$ & $-7,29$ \\
\hline Owner occup. & 0,3126 & 3,74 & 0,3138 & 3,75 & 0,3102 & 3,71 \\
\hline Age $\leq 59$ & $-4,9478$ & $-23,17$ & $-4,8577$ & $-22,30$ & $-4,9335$ & $-23,00$ \\
\hline Age $=60$ & $-3,3805$ & $-16,45$ & $-3,3655$ & $-16,52$ & $-3,4124$ & $-16,90$ \\
\hline Age $=61$ & $-1,8075$ & $-9,76$ & $-1,8030$ & $-9,84$ & $-1,8392$ & $-10,11$ \\
\hline Age $=62$ & $-1,3567$ & $-7,38$ & $-1,3548$ & $-7,42$ & $-1,3793$ & $-7,57$ \\
\hline Age $=63$ & $-1,1024$ & $-5,96$ & $-1,1059$ & $-5,98$ & $-1,1015$ & $-5,96$ \\
\hline Age $=64$ & $-0,3248$ & $-1,62$ & $-0,3287$ & $-1,64$ & $-0,3238$ & $-1,62$ \\
\hline Age $=66$ & 1,3876 & 4,26 & 1,3860 & 4,25 & 1,3875 & 4,26 \\
\hline Age $=67$ & 0,8107 & 2,79 & 0,8063 & 2,77 & 0,8116 & 2,79 \\
\hline Age $\geq 68$ & 1,0325 & 4,13 & 1,0308 & 4,12 & 1,0326 & 4,13 \\
\hline Constant & 2,9713 & 13,67 & 2,9662 & 13,65 & 2,9718 & 13,67 \\
\hline Log likelihood & \multicolumn{2}{|c|}{$-2343,6$} & \multicolumn{2}{|c|}{$-2342,1$} & \multicolumn{2}{|c|}{$-2343,5$} \\
\hline Observations & \multicolumn{2}{|c|}{8577} & \multicolumn{2}{|c|}{8577} & \multicolumn{2}{|c|}{8577} \\
\hline
\end{tabular}

Notes: Dependent variable is dummy variable „retired“. Log likelihood value at zero is 5954.1.

Prediction success rates are high and vary from 88.7 to 89.3 . This fit compares favorably to the baseline probability of 67.9 percent of retirees in our working sample. Except for the difference among the option value coefficients, all other coefficient estimates are fairly close to each across the six specifications. 
The other economic incentives for retirement, namely the wealth variables, are only partially significant. The GSOEP data does not contain levels of wealth and provides only indicators whether certain portfolio components - firm pension, life insurance, stock and bonds, and real estate - are present. There are many missing values, here coded as ,not present". In general, presence of financial and real wealth decreases the retirement probability. This is not particularly plausible for the presence of a firm pension. However, significant firm pensions are rare in Germany and usually indicate higher valued jobs in which retirement may occur later for reasons not related to the firm pension per se.

The pattern of age dummies reflects the obvious: older workers are more likely retired than younger ones. It is important to measure the option value with the age dummies included in order to purge its estimated coefficient from all other non-economic effects. The omission of age dummies about triples the estimated coefficient of the option value. Quite noticeable is the lack of any spikes in the pattern of age dummies. In this sense, retirement behavior is correctly described by the option value, the main economic incentive for retirement.

Most other socio-demographic variables are not significant. The important differences in social security regulations between men and women (women can retire at age 60 if have at least 15 years of retirement insurance history, while men need 35 years to retire at age 63 , unless they claim disability) appears to be fully captured by the option value. Marital status and education is also insignificant. We did not do full justice to the retirement subsystem for civil servants. They are actually treated as if they were part of the standard social security system which is not really the case. Civil servants are required to work longer than other employees, with a fairly rigid retirement age at 65 , although claims to disability are frequent as well as early retirement due to downsizing of the civil service sector. We find an expected negative coefficient, indicating later retirement for civil servants.

One may be suspicious that a simple logit model biases results because it ignores the panel nature of our working sample. We therefore employ a panel probit model that permits a combination of random effects and serial correlation. This model follows Börsch-Supan (1999) where all necessary econometric details are presented. It is estimated by numerical simulation methods, see Börsch-Supan and Hajivassiliou (1993). The model can be interpreted as a semi-nonparametric hazard model for multiple spell data permitting unobserved heterogeneity and state dependence. It is non-parametric in the sense that the model does not 
impose a functional form on the duration in a given state. Fairly flexible hazard rate models of retirement have been estimated by Sueyoshi (1989) and Meghir and Whitehouse (1997), however, not in combination with an option value describing the incentives to retire. Parametric hazard rate models for German data have been estimated by Schmidt (1995) and Börsch-Supan and Schmidt (1996). 
Table 3: Multiperiod probit model of the retirement decision

\begin{tabular}{|c|c|c|c|c|c|c|}
\hline \multirow[b]{2}{*}{ Variable } & \multicolumn{2}{|c|}{$\begin{array}{l}\text { MODEL 1: } \\
\text { i.i.d. }\end{array}$} & \multicolumn{2}{|c|}{$\begin{array}{l}\text { MODEL 2: } \\
\text { RAN }\end{array}$} & \multicolumn{2}{|c|}{$\begin{array}{l}\text { MODEL 3: } \\
\text { RAN+AR1 }\end{array}$} \\
\hline & Parameter & $t-S t a t$ & Parameter & t-Stat & Parameter & t-Stat \\
\hline Option value & $-0,0028$ & $-3,38$ & $-0,0110$ & $-6,04$ & $-0,0115$ & $-6,81$ \\
\hline Health & $-0,1349$ & $-9,97$ & $-0,1029$ & $-3,68$ & $-0,0865$ & $-3,26$ \\
\hline Female & 0,0745 & 1,11 & $-0,0678$ & $-0,31$ & $-0,1195$ & $-0,59$ \\
\hline Married & $-0,0177$ & $-0,23$ & $-0,0153$ & $-0,07$ & $-0,0449$ & $-0,36$ \\
\hline Education & $-0,4115$ & $-3,96$ & $-0,6257$ & $-2,00$ & $-0,6020$ & $-1,88$ \\
\hline Civil servant & 0,3536 & 3,16 & 1,0587 & 3,04 & 1,0337 & 2,95 \\
\hline Firm pension & $-2,0030$ & $-10,93$ & $-2,3893$ & $-8,14$ & $-2,2043$ & $-7,95$ \\
\hline Life insurance & $-0,0969$ & $-1,62$ & $-0,2577$ & $-2,00$ & $-0,2123$ & $-1,72$ \\
\hline Stocks/bonds & $-0,0028$ & $-0,04$ & $-0,1340$ & $-0,86$ & $-0,1286$ & $-0,89$ \\
\hline Real estate & $-0,6298$ & $-7,42$ & $-0,9597$ & $-5,04$ & $-0,8639$ & $-4,76$ \\
\hline Owner occup. & 0,2175 & 3,42 & $-0,1036$ & $-0,55$ & $-0,1138$ & $-0,64$ \\
\hline Age $\leq 59$ & $-3,8816$ & $-24,81$ & $-7,6382$ & $-21,01$ & $-7,2894$ & $-24,02$ \\
\hline Age $=60$ & $-2,8372$ & $-18,24$ & $-5,6820$ & $-18,00$ & $-5,4844$ & $-20,32$ \\
\hline Age $=61$ & $-1,5157$ & $-10,58$ & $-3,1143$ & $-12,13$ & $-2,9953$ & $-12,70$ \\
\hline Age $=62$ & $-1,1331$ & $-7,85$ & $-2,2996$ & $-9,46$ & $-2,2247$ & $-9,79$ \\
\hline Age $=63$ & $-0,8955$ & $-6,10$ & $-2,0115$ & $-8,44$ & $-1,9826$ & $-9,05$ \\
\hline Age $=64$ & $-0,2588$ & $-1,66$ & $-0,4417$ & $-1,84$ & $-0,4516$ & $-2,06$ \\
\hline Age $=66$ & 0,9843 & 4,46 & 1,9338 & 5,68 & 1,8089 & 5,82 \\
\hline Age $=67$ & 0,5858 & 2,83 & 1,3707 & 4,16 & 1,3116 & 4,29 \\
\hline Age $\geq 68$ & 0,7606 & 4,24 & 1,8981 & 6,35 & 1,8450 & 6,36 \\
\hline Constant & 2,3834 & 14,46 & 3,9641 & 10,87 & 3,7499 & 13,94 \\
\hline RAN & & & 2,8358 & 19,85 & 2,8356 & 13,58 \\
\hline AR 1 & & & & & 0,6093 & 10,66 \\
\hline Log likelihood & -2350 & & -1808 & & -1778 & \\
\hline Individuals & $857^{\circ}$ & & 1610 & & 161 & \\
\hline Max. periods & 1 & & 13 & & 13 & \\
\hline Observations & 857 & & $857^{\prime}$ & & 857 & \\
\hline
\end{tabular}

Notes: Dependent variable is the dummy variable ,retired“. Log likelihood value at zero parameter values is 5954.1. All estimates based on 20 replications in simulated maximum likelihood estimator.

We estimate three models, using the probabilistic version of the option value based on the full regression (Specification $4 \mathrm{c}$ in Tables 1 and 2). Model 1 has i.i.d. errors and corresponds to the logit model of Table $2 b$. Note that probit coefficient estimates are smaller by 
the square root of $\pi / 6$, that is 0.7797 , than their logit counterparts. Model 2 corrects for unobserved heterogeneity by a random effect whose standard deviation is reported at the bottom of Table 3. Finally, Model 3 adds an autoregressive error component to Model 2. Estimation results are presented in Table 3.

While even the simple i.i.d. model fits the data well (the pseudo- $\mathrm{R}^{2}$ - one minus the ratio of the likelihood at the estimated parameters over the likelihood at zero - is 60.5 percent), introducing random effects increases the log likelihood significantly: the pseudo- $\mathrm{R}^{2}$ increases to 69.7 percent. The additional inclusion of an autoregressive component is also statistically significant, the pseudo- $\mathrm{R}^{2}$ now rises to 70.1 percent. The prediction success is about 89 percent for all three models, the same as for the logit models.

Our most important results relate to the coefficients of the option value. Taking account of the intertemporal correlations in the panel appears to be very important. The numerical value of the option value coefficient is severely underestimated in the i.i.d. model. With random effects (capturing individual specific unobserved variables) and an autoregressive error (capturing the declining influence of shocks, such as an illness), the coefficient estimate of the option value quadruples and is estimated much more precisely. This also holds for the “endogenous" specification, although to a lesser extent (see Börsch-Supan, 1999).

There is little change in the other explanatory variables across disturbance specifications with one important exception: the estimated coefficients of the health variable. It is coded 0 for „very poor" to 10 for „excellent". As expected, the coefficients are negative. Less healthy workers retire earlier. In the i.i.d. model, health is more significant than the option value. However, as soon as unobserved population heterogeneity is accounted for, this changes, and the estimated coefficient becomes somewhat smaller. This shows the importance to account for intertemporal linkages. In the absence of random effects, health appears to capture unmeasured population heterogeneity that is taken out by the random effects to the extent that it is time invariant.

\section{Conclusions}

Main point of the paper was to account for uncertainty and potential endogeneity of the expected retirement income in models measuring the incentive effects of public pension 
rules on early retirement. We were able to bracket the coefficient estimates in an option value model by the two extremes (all are eligible for disability benefits; nobody is eligible for disability benefits). However, using the endogenous specification (all those are ex ante eligible for disability benefits who have ex post disability status) yields a badly upward biased coefficient, i.e., it badly exaggerates the incentive effects of pension provisions. We employ an instrumental variable approach to correct for this endogeneity, using employment and human capital characteristics as instruments in a first stage regression that generates a fitted probability for the pathway "disabled".

We then proceeded to a more complicated stochastic model that accounts for random effects (capturing individual specific unobserved variables) and an autoregressive error (capturing the declining influence of shocks, such as an illness). Such a model can be interpreted as some convenient functional form to account for individual-specific deviations from the fitted expected retirement income as well, although the model is not structural since expected retirement income enters the option value in a complicated nonlinear fashion, due to the maximization over present discounted values. Our fullest specification yields a coefficient estimate of the option value that is quadrupled relative to the i.i.d. case. Moreover, and it is estimated much more precisely than by the i.i.d. model.

We thus have corrected for two effects vis-à-vis conventional models. First, we corrected for the exaggerated option value coefficient due to uncertainty and endogeneity of expected retirement income. Second, we corrected for the underestimated option value coefficient in a model that disregards the panel nature of the data. By chance, the two effects roughly compensate each other in our working sample of German workers aged 55-70.

What do the estimated magnitudes of the option value coefficients mean in practice? Using the full model in Table 3, we can simulate a shift from the currently less than actuarially fair system of adjustment factors (see Figure 2) to an actuarial fair system. This change would shift the cumulative retirement distribution function down from what it is currently, depicted in Figure 5. The effect is most dramatic for very early retirement where the discrepancy between disability and normal retirement incentives are the largest, see Figure 4. The policy change would cause retirement at ages 59 and below to drop from 28.6 percent to about 16.5 percent. 


\section{References}

Börsch-Supan, A., 1992, Population Aging, Social Security Design, and Early Retirement, Journal of Institutional and Theoretical Economics 148, 533-557.

Börsch-Supan, A., and Hajivassiliou, V., 1993, Smooth Unbiased Multivariate Probability Simulators for Limited Dependent Variable Models. Journal of Econometrics 58, 347 368.

Börsch-Supan, A., und R. Schnabel, 1998a, Social Security and Declining Labor Force Participation in Germany, American Economic Review 88.2, 173-178.

Börsch-Supan, A., und R. Schnabel, 1998b, Social Security and Retirement in Germany, in: J. Gruber and D.A. Wise (eds), International Social Security Comparions, University of Chicago Press: Chicago, in press.

Bundesministerium für Arbeit und Sozialordnung (BMA), 1997, Statistisches Taschenbuch, Bonn: Bundespresseamt.

Burkhauser, R., 1991, An Introduction to the German Socio-Economic Panel For English Speaking Researchers, mimeo, Syracuse University

Gruber, J., and D.A. Wise (eds), 1999, Social Security and Retirement Around the World. University of Chicago Press: Chicago.

Lumbsdaine, R.L., J.H. Stock, and D.A. Wise, 1992, Three models of Retirement: Computational Complexity versus Predictive Validity, in D.A. Wise, ed., Topics in the Economics of Aging, Chicago: University of Chicago Press, 16-60.

Meghir, C. and E. Whitehouse, 1997, Labour Market Transitions and Retirement of Men in the UK, Journal of Econometrics 79, 327-354.

Rust, J., 1990, Behavior of Male Workers at the End of the Life Cycle: An Empirical Analysis of States and Controls, in: D.A. Wise (ed.) Issues in the Economics of Aging, Chicago: University of Chicago Press.

Rust, J., and C. Phelan, 1997, How Social Security and Medicare Affect Retirement Behavior in a World of Incomplete Markets, Econometrica 65(4), 781-831.

Schmidt, P., 1995, Die Wahl des Rentenalters - Theoretische und empirische Analyse des Rentenzugangsverhaltens in West- und Ostdeutschland, Lang, Frankfurt.

Stock, J.H., and Wise, D.A., 1990, The Pension Inducement to Retire: An Option Value Analysis, in: D.A. Wise (ed.) Issues in the Economics of Aging, Chicago: University of Chicago Press, 1990, 205-30.

Sueyoshi, G.T., 1989, Social Security and The Determinants of Full and Partial Retirement: A Competing Risk Analysis, NBER Working Paper 3113, Cambridge.

Verband deutscher Rentenversicherungsträger (VdR), 1997, Die Rentenversicherung in Zeitreihen, Frankfurt am Main. 
</ref_section> 